\title{
KINETIC DETERMINATION OF GOLD(III) BASED ON ITS INHIBITORY EFFECT IN OXIDIZING HOMOGENOUS REACTION SYSTEM
}

\author{
Ružica Micić ${ }^{1 *}$, Snežana Mitić2 ${ }^{2}$ Ranko Simonović ${ }^{1}$, Dragana Sejmanović ${ }^{1}$ \\ ${ }^{1}$ Faculty of Sciences and Mathematics, University of Pristina, Kosovska Mitrovica, Serbia. \\ ${ }^{2}$ Faculty of Sciences and Mathematics, University of Niš , Niš, Serbia.
}

\begin{abstract}
Development and application of a simple, fast, green analytical kinetic method for the determination of micro-amounts of gold(III ) ions, were presented in this paper. The method was based on the inhibitory effect of traces of $\mathrm{Au}$ (III) ions on the redox reaction between disodium-6hydroxy-5-[(4-sulfophenyl)azo]-2-naphtalenesulfonate (artificial azo-dye "Sunset Yellow FCF", E110 in further text selected as SY ) and hydrogenperoxide, in alkaline media of borate buffer. All experimental parameters affecting to the determination: reagent concentrations, $\mathrm{pH}$ and temperature were investigated and optimised. Working experimental conditions are set according to the highest sensitivity of the proposed kinetic

method for the determination of Au(III) ions. The linearity of the method was obtained within the range 1.97-59.07 $\mu \mathrm{g} / \mathrm{mL}$ of $\mathrm{Au}($ III) ions with relative standard deviation of $3.66-0.43 \%$, respectively. The influence by possible interference effects by major ions on the determination of $\mathrm{Au}(\mathrm{III})$ and their limits are investigated, at the constant $\mathrm{Au}(\mathrm{III})$ concentration of $39.39 \mu \mathrm{g} / \mathrm{mL}$. The results of $\mathrm{Au}(\mathrm{III})$ determination in samples obtained by proposed kinetic method and comparative ICP-OES method were statistically agreeable. Obtained results for $\mathrm{Au}$ (III) determination in analyzed samples, as well as the development and validation of the proposed analytical procedure have given and discussed.
\end{abstract}

Keywords: gold(III), kinetic method, sunset yellow.

\section{INTRODUCTION}

Chemistry of gold is still the subject of research in scientific articles, not only because of its beauty and rarity and usage in jewelry, coinage and economics. Many properties of a gold(III) and gold-nanoparticles as enzyme inhibitor, vehicles for delivery of cancer drugs, antirheumatics based on its coordination and valence state, in many electron transfer processes ((Chandrakant, et al., 2016), (Narkhede et al., 2016), (Yang et al., 2016), (Pyrzyńska et al., 2006). Modern sophisticated techniques such as inductively coupled plasma mass spectrometry (ICP-MS) (Juvonen et al., 2002), flame atomic absorption spectrometry (FAAS), electrothermal atomic absorption spectrometry (ETAAAS), inductively coupled plasma atomic emission spectrometry (ICP-AES) (Bulut et al., 2011), and other spectrophotometric methods involving chromogenic reagents such as morin, quercetin (Balcerzak et al., 2006), Spheron (R) and (biphenyl) dimethanethiol, (Behpour et al., 2005) etc. and electroanalytical techniques (square wave voltammetry-SWV, differential pulse voltammetryDPV etc.) (Bulut et al., 2011) are the most commonly used techniques in the determination of gold at low levels. UV-Vis spectrophotometric methods ((Chen et al., 2006), (Kamble et al., 2010)) are remarkable for their simplicity and versatility. Other sensitive techniques such as neutron activation analysis (NAA) (Nat et al., 2004) or total reflection X-ray fluorescence spectrometry (TXRF) (Messerschmidt et al., 2000) are less often applied in gold determination due to the complexity and cost of the required instrumentation.

Despite the large number of modern analytical techniques, kinetic methods still are used in real samples in the context of the study of the mechanism and rate of the chemical reactions. Also kinetic methods are preferred in terms of cost the experiment.

In this study simple and fast kineticspectrophotometric method was developed, based on inhibitory effect of gold(III). Experimental conditions were optimized as follow: $\mathrm{C}_{\mathrm{SY}}=4 \cdot 10^{-5} \mathrm{~mol} / \mathrm{L}$; $\mathrm{CH}_{2} \mathrm{O}_{2}=0.4 \mathrm{~mol} / \mathrm{L} ; \quad \mathrm{pH}=10.5 ; \quad \mathrm{t}=25.0 \pm 0.1^{\circ} \mathrm{C}$. Measurements were done at the wavelength of absorbance maximum of the indicator substance- 
artificial color "Sunset Yellow FCF, at $\lambda \max =478.4$ $\mathrm{nm}$.

\section{EXPERIMENTAL}

\subsection{Apparatus}

Spectrophotometric measurements were performed on Perkin-Elmer Lambda 15 UV-Vis spectrophotometer, using cylindrical cell thermostated at $25.0 \pm 0.1^{\circ} \mathrm{C}$. A Julabo MP-5A model thermostatic bath was used to maintain the reaction temperature at $25.0 \pm 0.1^{\circ} \mathrm{C}$. A pH meter (Hanna $\mathrm{pH}-210$ ) with a glass electrode was employed for measuring $\mathrm{pH}$ values in the aqueous solution. 01 and $\mathrm{pH}$ of $4.00 \pm 0.01$, were used. iCAP 6000 ICP-OES, Thermo Scientific, Cambridge, United Kingdom.

\subsection{Reagents and Solutions}

Analytical grade chemicals and deionized water (MicroMed high purity water system, TKA Wasseraufbereitungssysteme $\mathrm{GmbH}$ ) were used for the preparation all of solutions. The stock $\mathrm{Au}(\mathrm{III})$ solution $\left(1 \times 10^{-3} \mathrm{~mol} / \mathrm{L}\right)$ was prepared by dissolving $\mathrm{Au}\left[\mathrm{HCl}_{4}\right]$ (Alfa Aeser, A Jonson Matthey Company) in demineralized water. A working solution $\left(1 \times 10^{-5}\right.$ mol /L) was obtained by diluting the stock solution with water. A solution of SY (provided by the Pharmaceutical laboratory Zdravlje-Actavis, Leskovac, Serbia), of $1 \times 10^{-3} \mathrm{~mol} / \mathrm{L}$, was prepared by measuring $0.0226 \mathrm{~g}$ of substance of analytical grade, and dissolving with deionized water in a volumetric flask of $50 \mathrm{ml}$. A solution of $\mathrm{H}_{2} \mathrm{O}_{2}$ of $2 \mathrm{~mol} / \mathrm{L}$ was prepared by appropriate dilution of $30 \% \quad \mathrm{H}_{2} \mathrm{O}_{2}$, (Merck) of reagent in volumetric flask of $50 \mathrm{~mL}$ with deionized water. The solution of borate buffer was prepared by appropriate mixing a solution of $\mathrm{Na}_{2} \mathrm{~B}_{4} \mathrm{O}_{7} \times 10 \mathrm{H}_{2} \mathrm{O}(0.05 \mathrm{~mol} / \mathrm{L})$ and $0.1 \mathrm{~mol} / \mathrm{L}$ solution of $\mathrm{NaOH}$. All the glassware used was washed with aqueous solution of $\mathrm{HCl}(1: 1)$ and then thoroughly rinsed with running, distilled water, and then, finally with deionized water.

\subsection{Kinetic-Spectrophotometric procedure}

Bouderin flask with a four compartment was used for preparing solution (working volume of $5 \mathrm{ml}$ ) before the start of reaction; a series of standard solution of $\mathrm{Au}(\mathrm{III})$ were placed in the first compartment, $0.2 \mathrm{ml}$ of $1 \times 10-3 \mathrm{~mol} / \mathrm{L}$ solution of $\mathrm{SY}$ in the second, $2 \mathrm{ml}$ borate buffer $\mathrm{pH}$ of 10.5 in the third and $1 \mathrm{ml}$ of $2 \mathrm{~mol} / \mathrm{L} \mathrm{H}_{2} \mathrm{O}_{2}$ in the fourth compartment. The solution was kept at $25.0 \pm 0.1^{\circ} \mathrm{C}$ in the thermostated bath, before the mixing and beginning of the reaction. After mixing the reaction mixture was put into the spectrophotometric cell with path-length of $1 \mathrm{~cm}$, and the absorbance at $478.4 \mathrm{~nm}$ was measured every $30 \mathrm{~s}$ during the first period of 6 min from the beginning of the reaction. The reaction rate was monitored spectrophotometrically. Absorbance measurements have been performed at the wavelength of the absorption maximum of SY at 478.4 nm.

Sample preparation. After the preparation of the sample solution injections containing the Au (III) ions in a concentration of $50 \mathrm{mg} / 0.5 \mathrm{~mL}$, based on the weight of the salt of sodium thio-auro-maleate $\mathrm{Na}_{2} \mathrm{SAuO}_{4}$, was transferred quantitatively to the volumetric flasks of $50 \mathrm{~mL}$ and diluted with demineralized water to line. The concentration of this solution, calculated with respect to the $\mathrm{Au}$ (III) ion was $58 \mathrm{mg} / \mathrm{mL}$. From this solution were made series of four different concentrations of $\mathrm{Au}$ (III) which are located in the area of the calibration curve: 58.0, 29.1, $14: 5$, and $4.8 \mathrm{mg} / \mathrm{mL}$

\section{RESULTS AND DISCUSSION}

\subsection{Optimization of Reaction Variables}

Inhibiting effect of $\mathrm{Au}(\mathrm{III})$ ion on the rate of reaction oxidation of $d i$-sodium-6-hydroxy-5-[(4sulfophenyl)azo]-2-naphtalenesulfonic acid (artificial color Sunset Yellow FCF, E110) by hydrogen peroxide in borate buffer was observed during kinetic research of this indicator system (Micic et al. 2009, 2014). In order to determine the lowest possible deterable concentration of $\mathrm{Au}(\mathrm{III})$, the reaction conditions ( the influence of the $\mathrm{pH}$, SY, hydrogenperoxide concentrations, buffer volume and temperature) were studied for both, non-inhibited and inhibited reactions. The method of tangents was used and the slope of the linear section absorbance-time curve, $\mathrm{dA} / \mathrm{dt}=\operatorname{tg} \alpha$, was used as a measure of the reaction rate. In this study, for all parameters investigated, the rates of non-inhibited (indicator) and inhibited reaction were simultaneously measured.

Keeping all other experimental parameter constant, the influence of the $\mathrm{pH}$ in borate buffer on the rate of the reactions in the range of $8.0-11.5$ were studied, under concentration of gold(III) of $39.4 \mu \mathrm{g} / \mathrm{mL}$. The 
influence of $\mathrm{pH}$ on the reaction rates were separately measured with the same method by varyng the $\mathrm{pH}$. The best results were obtained for the value $\mathrm{pH}$ of 10.5 (Fig. 1), and this value was selected for further work. the order for both reactions, are variable in investigated interval regarding to $\mathrm{pH}$. In order to obtain the rate of reactions regarding to $\mathrm{C}_{\mathrm{H}+}$ the dependence $-\log \operatorname{tg} \alpha /-\log \mathrm{C}_{\mathrm{H}+}$ within interval of $\mathrm{pH}$ 9.5-10.5 were constructed. Based on the slope of this dependence the order of the reactions were calculated. Its value for non-inhibited raction is -0.9 and for inhibited is -0.5 . (Fig. 3 and 4). The dependence of the reaction rates for both reactions, on the volume of borate buffer was also studied. The optimum difference between the rate of the non-inhibited and inhibited reactions is for volume of $2.0 \mathrm{~mL}$ of borate buffer, Fig. 4 . The dependence of the reaction rates on the concentration of $\mathrm{H}_{2} \mathrm{O}_{2}$ were investigated over the range $0.1-0.8 \mathrm{~mol} / \mathrm{L}$, Fig. 5. For further work, a concentration of $\mathrm{H}_{2} \mathrm{O}_{2}$ of $0.4 \mathrm{~mol} / \mathrm{L}$ was selected as the suitable. The dependence of reaction rates on the concentration of SY was investigated over the range $1.0 \times 10^{-5}-6 \times 10^{-5} \mathrm{~mol} / \mathrm{L}$. The optimum difference between the rates of the non-inhibited and inhibited reactions occurred for concentration of $4.0 \times 10^{-5} \mathrm{~mol} / \mathrm{L}$ of SY, Fig.6. At higher concentration of SY absorbance significantly increases $(A>1.0)$, when error of spectrophotometric measurement becomes higher (area of Beer's low validity). The influence of temperature on the reaction rate was studied in the range $22^{\circ} \mathrm{C}-28^{\circ} \mathrm{C}$. The rate of reaction as expected increases with temperature. Although higher sensitivity could be obtained at the higher reaction temperature, for practical reasons measurement were done at $25 \pm 0.1^{\circ} \mathrm{C}$. On the basis of dependence of rates of reactions on the concentration of each reactant, kinetic equations for non-inhibited (1) and inhibited reactions can be derived as follows:

$$
\begin{aligned}
& -\left(\frac{d C}{d t}\right)=k_{0} \cdot C_{H+}^{-0.9} \cdot C_{S Y} \\
& -\left(\frac{d C}{d t}\right)=k \cdot C_{H+}^{-0.5} \cdot C_{S Y} \cdot C_{A u(I I I)}^{-1}
\end{aligned}
$$

Where $\mathrm{k}_{0}$ is constant which is proportional to the constant rate of non-inhibited reaction, and $\mathrm{k}$ is constant which is proportional to the constant of inhibited reaction. Based on kinetic equations (1) and (2) rate constants were calculated for non-inhibitory and inhibitory reactions in the temperature range of $22-25^{\circ} \mathrm{C}(295-301 \mathrm{~K})$, and obtained results are shown in Table 1.

Based on the Arrhenius's equation for non- inhibitory and inhibitory reactions Arrhenius's plot has obtained (Fig.7., 8.) the activation energy $\left(E_{a}^{*}\right)$ were calculated by following equation, for both process, non-inhibited and inhibited:

$$
E_{a}^{*}=-R\left[\frac{\partial \ln k}{\partial(1 / T)}\right]_{P}
$$

Based on its value and thermodynamics equations for change of Gibbs's energy, enthalpy $(\mathrm{H})$ and enthropy (S) can calculated for both processes. Based on this results mechanism of examined redox reactions can be discussed under given experimental conditionsconcentration of reaction parameters, at room temperature and atmospheric pressure in examined redox system.

Table 1. Rate constants.

\begin{tabular}{|c|c|c|}
\hline $\mathrm{T}(\mathrm{K})$ & $\mathrm{k}_{0} \cdot 10^{8}(\mathrm{~mol} / \mathrm{l})^{1-\mathrm{n}} \mathrm{S}^{-1}$ & $\mathrm{k} \cdot 10^{8}(\mathrm{~mol} / \mathrm{l})^{1-\mathrm{n}} \mathrm{S}^{-1}$ \\
\hline 295 & 3.55 & 1.41 \\
\hline 298 & 6.65 & 4.22 \\
\hline 301 & 7.98 & 13.4 \\
\hline
\end{tabular}

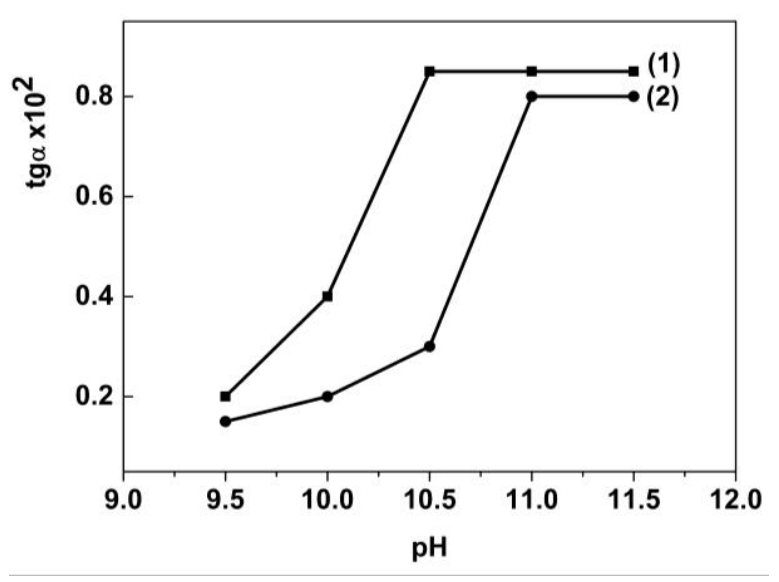

Fig. 1 The influence of $\mathrm{pH}$.

\section{Chemistry}




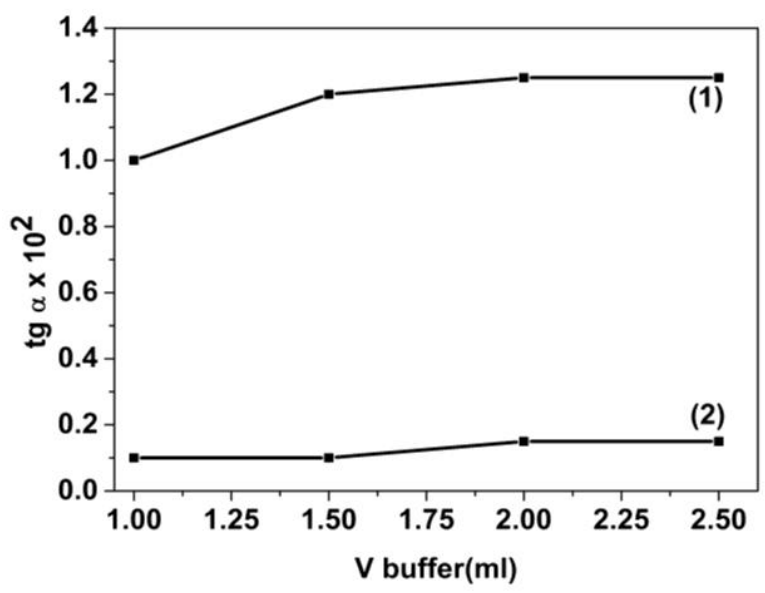

Fig. 2 The influence of borate buffer.

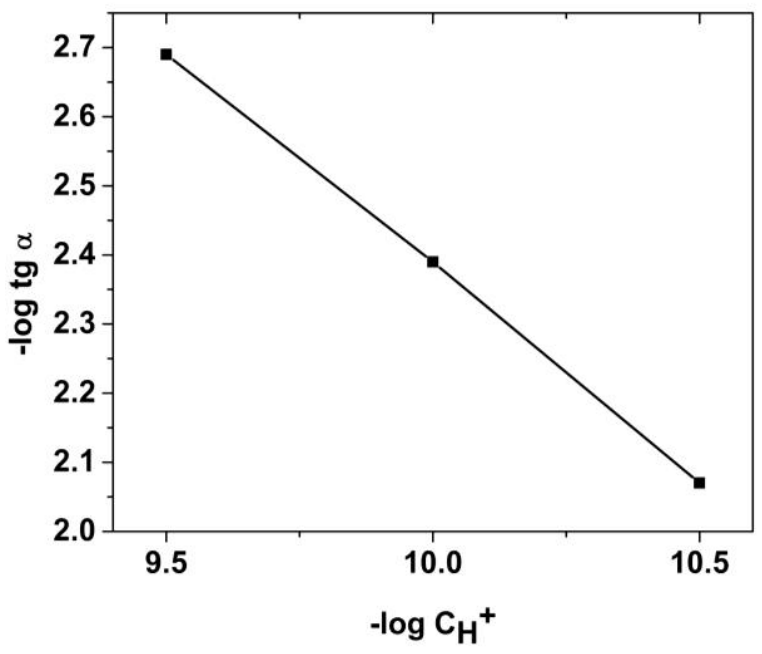

Fig. 3 Dependence $-\log \operatorname{tg} \alpha /-\log \mathrm{C}_{\mathrm{H}_{+}}$-non-inhibited.

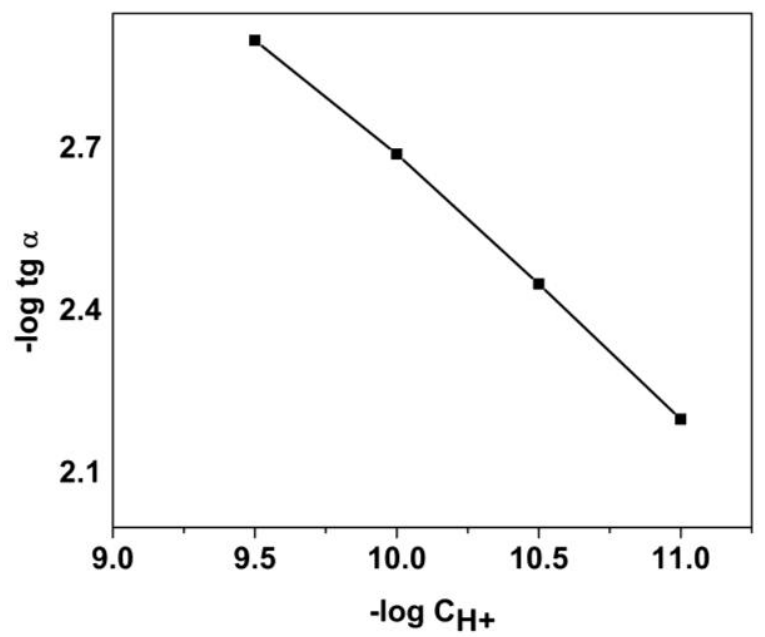

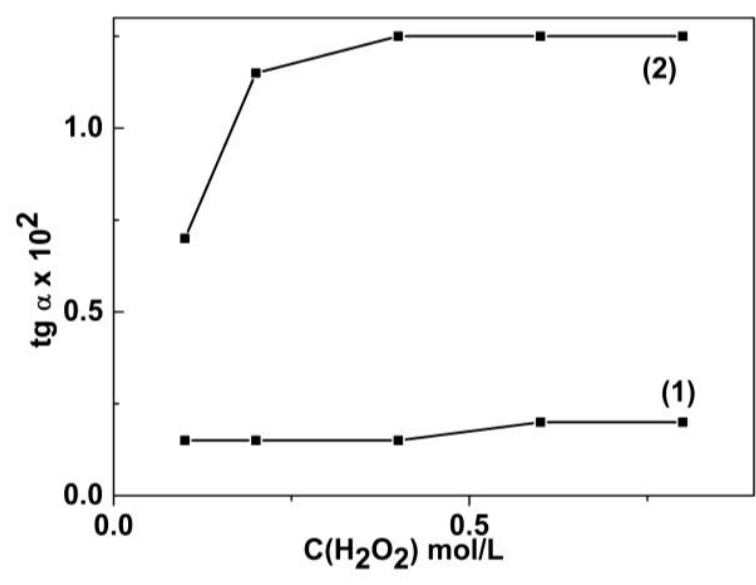

Fig. 5 The influence of $\mathrm{H}_{2} \mathrm{O}_{2}$.

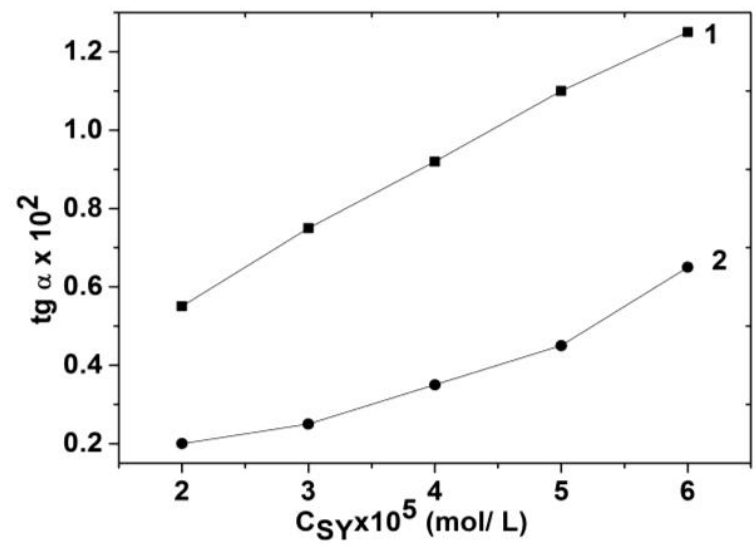

Fig. 6 The influence of SY.

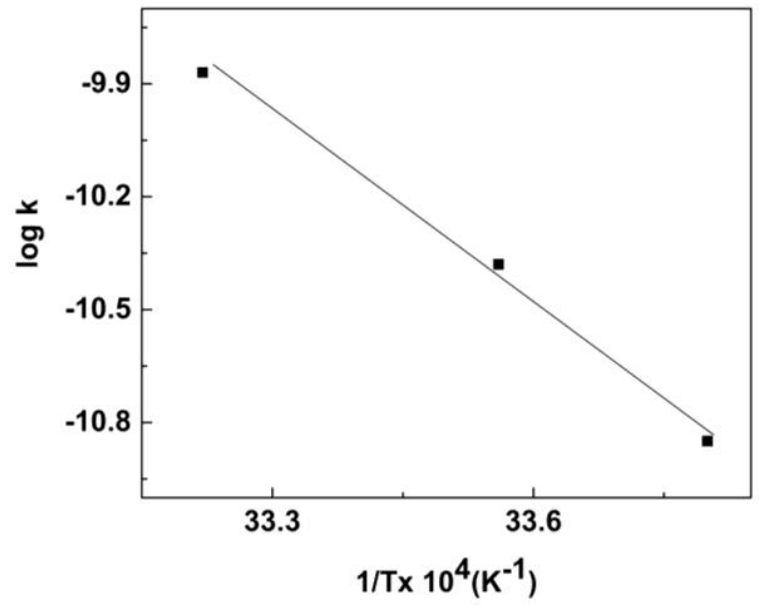

Fig. 7 Arrhenius' plot for inhibited reaction.

Fig. 4 Dependence $-\log \operatorname{tg} \alpha /-\log \mathrm{C}_{\mathrm{H}+}$-inhibited. 


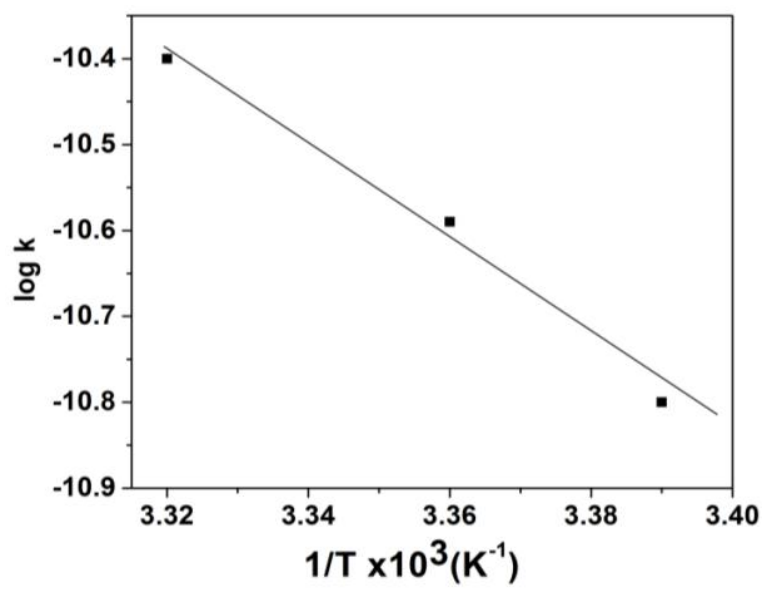

Fig. 8 Arrhenius' plot for non-inhibited reaction.

\subsection{Validation of the proposed method}

The calibration graph was constructed under the established optimal conditions regarding on sensitivity and reproducibility of the method as follows: $\mathrm{C}_{\mathrm{SY}}=4 \times 10^{-5} \mathrm{~mol} / \mathrm{L} ; \quad \mathrm{C}_{\mathrm{H} 2 \mathrm{O} 2}=0.4 \mathrm{~mol} / \mathrm{L} ; \quad \mathrm{pH}=10.5 ; \quad \mathrm{t}$ $=25.0 \pm 0.1^{\circ} \mathrm{C}, \lambda \max =478.4 \mathrm{~nm}$. The linearity was obtained within the range 1.97-59.07 $\mu \mathrm{g} / \mathrm{mL}$ of $\mathrm{Au}(\mathrm{III})$. Obtained analytical and statistical data of the calibration graph at $25.0 \pm 0.1^{\circ} \mathrm{C}$ were presented in Table 2. In order to assess the precision and accuracy of the proposed kinetic method, measurements were done in five replicate determinations at each of four different $\mathrm{Au}(\mathrm{III})$ concentrations. Obtained results are show in Table 3.

Table 2. Analytical and statistical data.

\begin{tabular}{|c|c|}
\hline \multirow{2}{*}{$\begin{array}{l}\text { Analytical and } \\
\text { Statistical Data }\end{array}$} & $\begin{array}{l}\text { Temperature } \\
25.0 \pm 0.1^{\circ} \mathrm{C}\end{array}$ \\
\hline & $\begin{array}{c}\text { Dynamic range 1.97-59.07 } \\
(\mu \mathrm{g} / \mathrm{mL})\end{array}$ \\
\hline Number of points & 9 \\
\hline $\begin{array}{l}\text { Limit of detection } \mu \mathrm{g} \\
\qquad / \mathrm{mL}\end{array}$ & 0.12 \\
\hline $\begin{array}{c}\text { Limit of quantification } \\
\mu \mathrm{g} \mathrm{mL}^{-1}\end{array}$ & 0.36 \\
\hline Slope $\times 10^{2}$ & -0.0126 \\
\hline Intercept $\times 10^{2}$ & 0.8948 \\
\hline Corelation Coefficient & -0.9997 \\
\hline $\begin{array}{c}\text { Standared error of the } \\
\text { slope }\end{array}$ & $1.217 \times 10^{-4}$ \\
\hline $\begin{array}{l}\text { Standared error of the } \\
\text { intercept } \times 10^{2}\end{array}$ & 0.00382 \\
\hline $\begin{array}{c}\text { Standard deviation of } \\
\text { the Fit } \times 10^{2}\end{array}$ & 0.00382 \\
\hline Analytical frequency, $\mathrm{h}_{1}^{-}$ & 10 \\
\hline
\end{tabular}

The robustness of proposed method is a measure of its capacity to remain unaffected by small, but deliberate variations in the method parameters and provides an indication of its reliability during usage. The most significant variables of the system (temperature and concentration of SY, hydrogen peroxide) were modified in range $\pm 10 \%$ (excluding $\mathrm{pH}$, which was modified in range $\pm 5 \%$ ) from their optimum values. Errors lower than $5 \%$ were observed in all cases.

Table 3. Accuricy and precision of the method.

\begin{tabular}{|c|c|c|c|}
\hline$\underset{\left.\mathrm{mL}^{-1}\right)}{\operatorname{Added}(\mu \mathrm{g}}$ & $\begin{array}{c}\text { Found }^{\mathrm{a}} \\
\left(\mu \mathrm{g} \mathrm{mL}^{-1}\right)\end{array}$ & $\begin{array}{c}\text { RSD }^{\mathbf{b}} \\
(\%)\end{array}$ & $(\mathrm{x}-\mu) / \mu \cdot 100^{c}$ \\
\hline 1.9 & $1.9 \pm 0.07$ & 3.7 & -3.1 \\
\hline 19.7 & $19.9 \pm 0.6$ & 3.2 & +1.1 \\
\hline 39.4 & $38.8 \pm 0.4$ & 1.0 & -1.5 \\
\hline 59.1 & $58.8 \pm 0.2$ & 0.4 & -0.4 \\
\hline
\end{tabular}

To access the selectivity of the method, the influence of major foreign ions on the inhibited reaction rate was studied, under the reaction conditions mentioned above, at a constant $\mathrm{Au}(\mathrm{III})$ concentration of $\mathrm{C}_{\mathrm{Au}(\mathrm{III})}=39.39 \mu \mathrm{g} / \mathrm{mL}$. The results are summarized in Table 4.

Table 4. Selectivity of the proposed method.

\begin{tabular}{|c|c|}
\hline $\begin{array}{c}\text { Ratio } \\
\mathrm{C}_{\text {other }} \\
\text { ion } / \mathrm{C}_{\mathrm{Au}(\text { III) }} \\
\end{array}$ & Other ions \\
\hline 100 & $\mathrm{Na}^{+}, \mathrm{K}^{+}, \mathrm{Cl}^{-}$ \\
\hline 10 & $\begin{array}{c}\mathrm{F}^{-}, \mathrm{Li}^{+}, \mathrm{Zn}^{2+}, \mathrm{Al}^{3+}, \mathrm{Mg}^{2+}, \mathrm{V}^{5+}, \mathrm{As}^{3+}, \mathrm{As}^{5+} \\
\mathrm{SO}_{3}^{2-}, \mathrm{NH}_{4}^{+}, \mathrm{CH}_{3} \mathrm{COOH}, \mathrm{Sn}^{2+}, \mathrm{Sr}^{2+} \mathrm{I}^{-}, \\
\mathrm{CO}_{3}{ }^{2-}\end{array}$ \\
\hline 1 & $\begin{array}{c}\mathrm{Mo}^{6+}, \mathrm{Cr}^{6+}, \mathrm{Ba}^{2+}, \mathrm{Cd}^{2+}, \mathrm{Ni}^{2+}, \mathrm{Mn}^{2+}, \mathrm{Al}^{3+} \\
\mathrm{Ca}^{+2} \mathrm{NO}_{3}^{-}, \mathrm{SO}_{4}^{2-}, \mathrm{C}_{2} \mathrm{O}_{4}{ }^{2-}\end{array}$ \\
\hline 0.1 & $\mathrm{Fe}^{3+}, \mathrm{Co}^{2+}, \mathrm{Hg}^{2+}$ \\
\hline
\end{tabular}

\subsection{Application of the proposed method}

In order to evaluate of proposed procedure this kinetic method was applied to the determination of $\mathrm{Au}(\mathrm{III})$ ions in pharmacological samples, ampoules Tauredon ( ${ }^{1}$ with $\mathrm{Au}(\mathrm{III})$ ions concentration of 50 $\mathrm{mg} / 0.5 \mathrm{~mL},\left(\mathrm{Na}_{2} \mathrm{SAuO}_{4}\right)$. Obtained results are given in 
Table 5. As can see results obtained by proposed kinetic and comparable ICP-OES method are in good agreement.

Table 5. Application in ampules Tauredon®.

\begin{tabular}{|c|c|c|c|c|}
\hline $\begin{array}{c}\text { Added } \\
(\mu \mathrm{g} / \mathrm{mL}) \\
\begin{array}{c}\text { Tauredon } \\
\circledR\end{array}\end{array}$ & $\begin{array}{c}\text { Found }^{\mathrm{a}} \\
(\mu \mathrm{g} / \mathrm{mL})\end{array}$ & $\begin{array}{c}\mathrm{RSD}^{\mathrm{b}} \\
(\%)\end{array}$ & $\begin{array}{c}\text { ICP-OES } \\
\text { Found }^{\mathrm{a}} \\
(\mu \mathrm{g} / \mathrm{mL})\end{array}$ & F-test \\
\hline 4.8 & $4.8 \pm 0.2$ & 3.1 & $4.8 \pm 0.2$ & 1.0 \\
\hline 14.5 & $14.4 \pm 0.5$ & 3.6 & $14.5 \pm 0.4$ & 1.6 \\
\hline 29.1 & $28.8 \pm 0.6$ & 2.2 & $29.0 \pm 0.3$ & 0.4 \\
\hline 58.1 & $57.2 \pm 0.8$ & 1.3 & $59.1 \pm 0.3$ & 0.7 \\
\hline
\end{tabular}

\section{CONCLUSION}

In this work fast, simple cost-effective, green analytical kinetic method for gold(III) determination was given. Application of the method was demonstrated in pharmacological ampoules Tauredon $®$. Method has good analytical performance and could be useful for trace determination of $\mathrm{Au}(\mathrm{III})$ ions in different kind of real samples. Thus, the proposed method was found to be robust for routine determination of $\mathrm{Au}(\mathrm{III})$ in different real samples.

\section{REFERENCES}

Balcerzak, M., Kosiorek, A., \& Swiecicka, E. 2006. Morin as a spectrophotometric reagent for gold. Journal of Analytical Chemistry,61, pp. 119123.

Behpour, M., Attaran, A.M., Ghoreishi, S.M., \& Soltani, N. 2005. Column preconcentration of gold by adsorbing AuCl4- onto methyltrioctyl ammonium chloride-naphthalene and subsequent atomic absorption spectrometric determination. Anal Bioanal Chem, 382(2), pp. 444-7. pmid:15838616.

Bulut, V.N., Duran, C., Boiyiklioglu, Z., Tufekci, M., \& Soylak, M. 2011. Spectrophotometric determination of gold(II) after liquid-liquid extraction and selective pre-concentration with a novel dibenzo-18-crown-derivates. Geostandards and Geoanalytical Research, 35(4), pp. 471-483.

Chen, Z., Huang, Z., Chen, J., Chen, J., Yin, J., Su, Q., \& Yang, G. 2006. Spectrophotometric determination of gold in water and ore with 2-Carboxyl-1-
Naphthalthiorhodanine. Analytical Letters, 39, pp. 579-587.

Juvonen, R., Lakomaa, T., \& Soikkeli, L. 2002. Determination of gold and the platinum group elements in geological samples by ICP-MS after nickel sulphide fire assay: Difficulties encountered with different types of geological samples. Talanta, 58(3), pp. 595-603. pmid:18968787.

Kamble, G.S., Kolekar, S.S., Han, S.H., \& Anuse, M.A. 2010. Synergistic liquid-liquid extractive spectrophotometric determination of gold(III) using 1-(2',4'-dinitro aminophenyl)-4,4,6-trimethyl-1,4dihydropyrimidine-2-thiol. Talanta, 81(3), pp. 108895. pmid:20298898.

Messerschmidt, J., von Bohlen, A., Alt, F., \& Klockenkämper, R. 2000. Separation and enrichment of palladium and gold in biological and environmental samples, adapted to the determination by total reflection X-ray fluorescence. Analyst, 125(3), pp. 397-9. pmid:10829339.

Micic, R.J., Mitić, S.S., \& Simonovic, R.M. 2009. Analytical application of food dye Sunset Yellow for the rapid kinetic determination of traces of copper(II) by spectrophotometry. Food Chemistry, 117(3), pp. 461-465.

Micic, R.J., Mitić, S.S., \& Budimir, M. 2009. Highly Sensitive Determination of Traces of Co(II) in Pharmaceutical and Urine Samples Using KineticSpectrophotometric Method. Analytical Letters, 42(7), pp. 935-947.

Micic, R.J., Mitić, S.S., Pavlovic, A.N., Kostic, A.D., \& Mitic, M.N. 2014. Application of tartrazine for sensitive and selective kinetic determination of $\mathrm{Cu}(\mathrm{II})$ traces. Journal of Analytical Chemistry, 69(12), pp. 1147-1152.

Narkhede, C.P., Suryawanshy, R.K., Patil, C.D., Borase, H.P., \& Patil, S.V. 2016. Use of protease inhibitory gold nanoparticles as a compatibility enhancer for Bt and deltamethrin: A novel approach for pest control. Biocatalysis and Agricultural Biotechnology, 8, pp. 8-12.

Nat, A., Ene, A., \& Lupu, R. 2004. Rapid determination of goLd in Romanian auriferous aLLuviaL sands, concentrates and rocks by $14 \mathrm{MeV}$ NAA. J Radional Nucl chem, 261, pp. 179-188.

Pyrzyńska，K. 2005. Recent developments in the determination of gold by atomic spectrometry techniques. Spectrochimica Acta Part B, 60, pp. 1316-1322.

Yang, Y., Zeng, H., Zhang, Q., Bai, X., Liu, C., \& Zhang, Y.H. 2016. Direct electron transfer and sensing performance for catechin nano-gold particles-polymer nano-composite with immobilized Laccase. Chemical Physics Letters, 658,pp. 259-269.

\footnotetext{
*E-mail: ruzica.micic@pr.ac.rs
} 